\title{
Ulcerative skin lesions in a child with colitis ulcerosa after colectomy
}

\author{
Leonarda Maria van Zitteren, ${ }^{1}$ H Jorn Bovenschen, ${ }^{2}$ Walter E Tjon a Ten ${ }^{1}$
}

${ }^{1}$ Pediatrics Department, Máxima Medical Center, Veldhoven, Netherlands;

2Dermatology Department, Máxima Medical Center, Veldhoven, Netherlands

Correspondence to Walter E Tjon a Ten, W.TjonaTen@mmc.nl

\section{DESCRIPTION}

A 17-year-old female patient was admitted to our hospital with large skin defects around her ileostoma since 6 months. Several years before, she underwent a colectomy due to colitis ulcerosa and an ileostoma was created. A sharply demarcated, deep peristomal ulcer was observed (figure 1). Despite intravenous antibiotics, the ulcer worsened and caused pain. Bloodcultures remained negative. The clinical diagnosis pyoderma gangrenosum (PG) was made, but skin biopsy was not performed because of the typical appearance. Treatment with $60 \mathrm{mg}$ oral prednisone was initiated and the ulcer rapidly improved (figure 2). $\mathrm{PG}$ is a rare, non-infectious, ulcerative skin disorder. Approximately $50 \%$ of the cases are associated with a variety of systemic diseases, such as arthritis, leukaemia or inflammatory bowel disease. Of the latter $0.6-5 \%$ develop PG. The pathogenesis is poorly understood. It is thought to be an immune dysregulation disorder with extensive neutrophil inflammation of the skin with vasculitis-like features. It most commonly occurs in women. Only $4 \%$ of all patients are children. ${ }^{1}$ Histology is aspecific. Diagnosis is made by clinical appearance and non-improvement after conservative or antibiotic treatment and is therefore often delayed. PG can occur all over the body. ${ }^{1} 2$ It often develops at sites of trauma such as biopsy and surgical scars. The first choice of treatment is systemic steroids combined with conservative wound care. However, treatment of the underlying disease is necessary. ${ }^{1}$ PG may heal after colectomy, although, like in our case, it has been described after colectomy. ${ }^{2}$ The prognosis remains unpredictable.

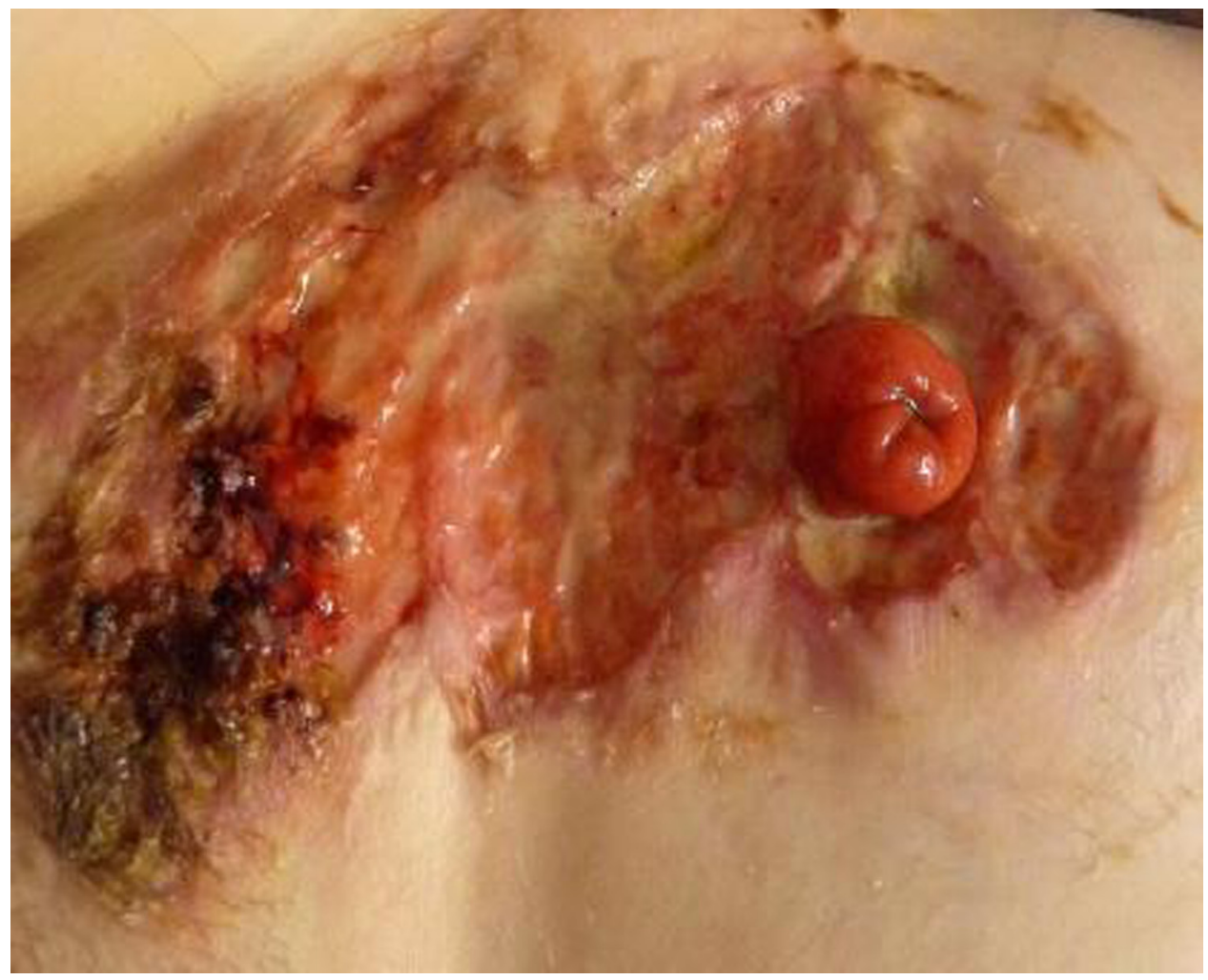

Figure 1 Peristomal lesion with yellow, red and black appearance and elevated borders, partly overhanging the ulcer bed. 


\section{BMJ Case Reports}

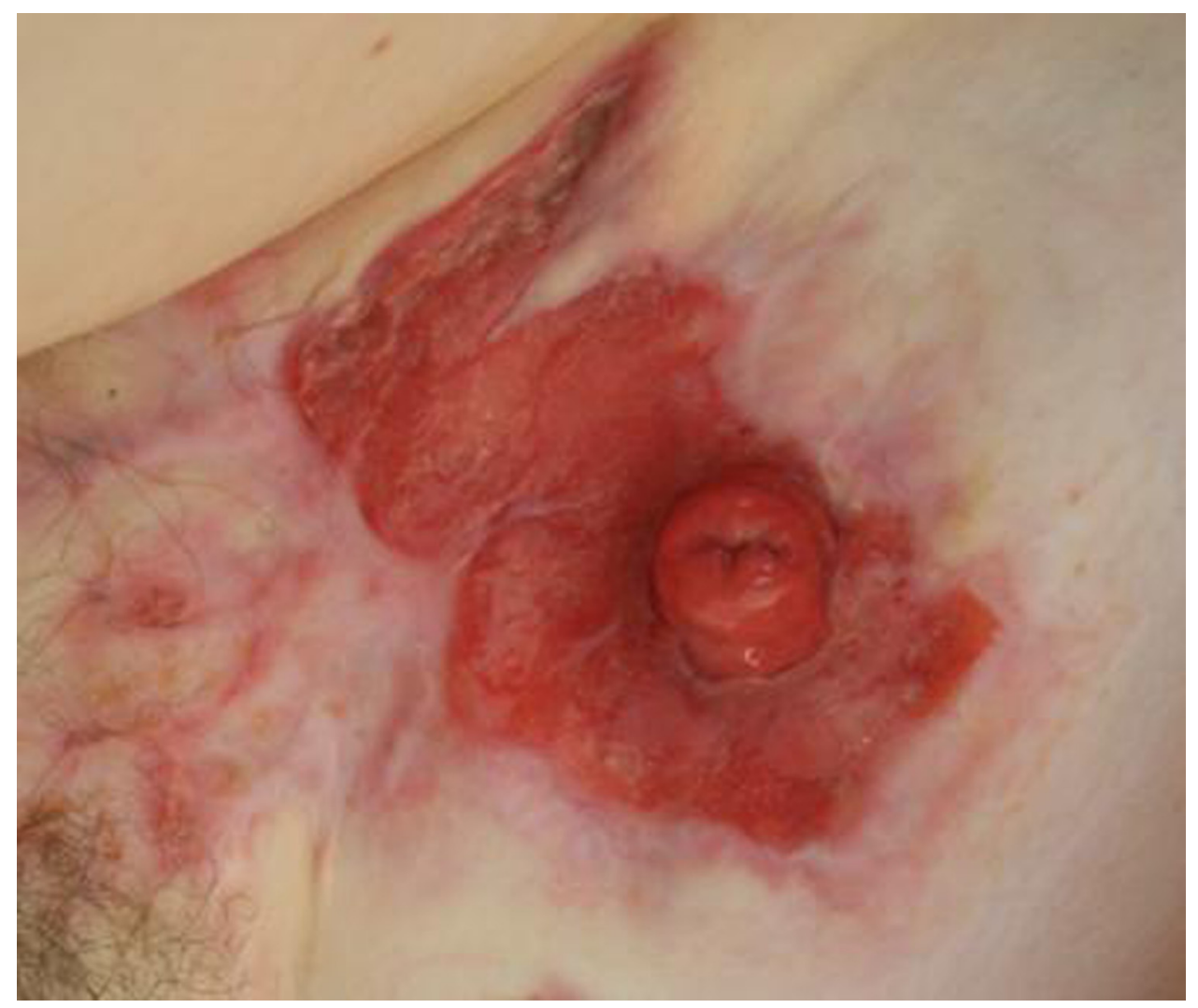

Figure 2 Peristomal lesion during treatment.

Competing interests None.

Patient consent Obtained.

\section{REFERENCES}

1. Callen JP. Pyoderma gangrenosum. Lancet 1998;351:581-5.

2. Hughes AP, Jackson JM, Callen JP. Clinical features and treatment of peristomal pyoderma gangrenosum. JAMA 2000;284:1546-8.

This pdf has been created automatically from the final edited text and images.

Copyright 2011 BMJ Publishing Group. All rights reserved. For permission to reuse any of this content visit http://group.bmj.com/group/rights-licensing/permissions.

BMJ Case Report Fellows may re-use this article for personal use and teaching without any further permission.

Please cite this article as follows (you will need to access the article online to obtain the date of publication).

van Zitteren LM, Bovenschen HJ, Tjon a Ten WE. Ulcerative skin lesions in a child with colitis ulcerosa after colectomy. BMJ Case Reports 2011;10.1136/bcr.10.2011.4998, Published XXX

Become a Fellow of BMJ Case Reports today and you can:

- Submit as many cases as you like

- Enjoy fast sympathetic peer review and rapid publication of accepted articles

- Access all the published articles

- Re-use any of the published material for personal use and teaching without further permission

For information on Institutional Fellowships contact consortiasales@bmjgroup.com

Visit casereports.bmj.com for more articles like this and to become a Fellow 